\title{
Economic clusters: A bridge between economic and spatial policies in the case of Beijing
}

\author{
Zhenshan Yang ${ }^{\mathrm{a}, 1}, \mathrm{Pu}_{\mathrm{Hao}}^{\mathrm{b}, *}$, Jianming Cai ${ }^{\mathrm{a}}$ \\ a Institute of Geographical Sciences and Natural Resources Research, Chinese Academy of Sciences, 11A Road, Datun, Chaoyang, Beijing 100101, China \\ ${ }^{\mathrm{b}}$ David C. Lam Institute for East-West Studies, Hong Kong Baptist University, Kowloon Tong, Hong Kong
}

\section{A R T I C L E I N F O}

\section{Article history:}

Received 6 February 2014

Received in revised form 10 June 2014

Accepted 17 June 2014

Available online 11 July 2014

\section{Keywords:}

Economic cluster

Urban planning

Spatial-economic space

Spatial-economic policy

Spatial approach

\begin{abstract}
A B S T R A C T
Economic clusters have been recognised as important elements of urban and regional economic strategies, but their role in spatial planning is under-appreciated. This paper examines the initiatives and outcomes of economic clusters in relation to urban spatial planning in the periods of planned and market economies in China. Through an examination of the planning and development practices in Beijing, the effect of economic clusters in facilitating local growth and shaping urban spatial structure is revealed. The significance of economic clusters in achieving synergy between economic and spatial policies is discussed.
\end{abstract}

(c) 2014 Elsevier Ltd. All rights reserved.

\section{Introduction}

There has been a long-standing plea to strengthen the effectiveness and efficiency of urban spatial planning under the regime of a market economy (Friedmann, 2005). As cities grow, realising this goal becomes more and more difficult because people and capital are increasingly mobile and the economic landscape of each urban section becomes increasingly specialised. The increasing mobility and specialisation are due largely to imperfectly competitive markets, increasing returns to scale and circular causation, all of which shape the economic and spatial landscapes in cities and stimulate competition among areas and regions (The World Bank., 2008). Some of the most important growth stimulators are economic clusters (ECs), which have proliferated in a wide spectrum of economic activities in the past three decades, from agriculture to high-tech industries and from consumer services to business finance. The role of ECs in economic development and urban growth has been studied extensively in various contexts including North America, Europe and East Asia (Audirac, 2003; Cortright, 2006; Hallencreutz \& Lundequist, 2003; Hospers, 2005; Rosenfeld, 2003).

An EC usually refers to a geographically bounded group of similar, interconnected and often complementary firms that share infrastructures and a common institutional environment. Due to

\footnotetext{
* Corresponding author. Tel.: +852 34115314.

E-mail addresses: yangzs@igsnrr.ac.cn (Z. Yang), puhao@me.com (P. Hao), caijm@igsnrr.ac.cn (J. Cai).

${ }^{1}$ Tel.: +861064889305.
}

the emergence of important and successful ECs, it has been widely suggested that government interventions should initiate and promote ECs to strengthen the local economy and regional competitiveness (Atherton, 2003; Porter, 1990; Rosenfeld, 1995). Many EC initiatives stem from economic policy agendas, with an interest in improving local economic performance with respect to income levels, employment, productivity, innovation and industrial structure (Bergman \& Feser, 1999; Ketels, 2003; Rosenfeld, 2003; Yang, Liang, \& Cai, 2014). Particularly, the diamond model, introduced by Porter (1990), generalises a path from cluster growth to local economic competitiveness by strengthening the interplay of productive and non-productive factors in economic development. As suggested by Broll and Roldán-Ponce (2011), ECs provide an analytical approach to planning as well as a policy instrument for promoting regional economic development. However, the role of ECs in connecting economic and spatial policies has not been systematically examined. As such, a comprehensive assessment of inter-connected economic and spatial developments is absent in policymaking, giving rise to sub-optimal planning decisions for cities and regions.

This paper, therefore, focuses on exploring the experience and potential of utilising ECs as an instrument to link economic and spatial policies. More specifically, the paper aims to provide answers to the following questions: (1) What is the theoretical and practical basis for using an EC to link economic and spatial policies? (2) How does an EC contribute to establishing such a linkage? (3) What are the consequences of EC development in a city for facilitating local growth and shaping the urban spatial structure? 
The empirical analysis of policy initiatives and outcomes of EC development is based on the case of Beijing, a city that has implemented a variety of initiatives for cluster-like development in the different periods of the planned economy and market economy. In the past 20 years, Beijing has employed ECs as a key strategy to foster new industries and enable the local economy, which links to the global market. With the development of ECs, Beijing has experienced a dramatic transformation of its urban spatial structure. This is accompanied by a huge influx of capital and the labour force, resulting in problems related to land use, transportation, environment and quality of life (Yang, Cai, Ottens, \& Sliuzas, 2013). To help exploit opportunities and cope with problems, the ECs in Beijing are examined as an instrument that can bridge economic and spatial policies to achieve synergy between urban economic and spatial developments. Because the effect of regionalor city-level cluster policy initiatives on the location decisions of firms in Beijing cannot be isolated from other factors determining such decisions (e.g., the desire to be located in the capital of China), the paper does not provide a general evaluation of the cluster concept regarding the economic performance of Beijing, but it does outline the interaction between the economic and spatial policies.

In the next section, we review the implications of a number of renowned cases of cluster development in contemporary urban development practice. The third section theoretically analyses the necessity and effectiveness of utilising the cluster concept to understand the urban structure. The fourth section provides an empirical analysis with respect to EC development and relevant policies in Beijing. The fifth section proposes an EC-based spatial approach to integrate cluster development into economic and spatial policies. The final section discusses the potential value of the EC-based approach in urban planning and suggests future research topics.

\section{Cluster-based urban spatial-economic dynamics}

The world economic landscape increasingly exhibits a clusterbased perspective (Scott and Storper, 1987; The World Bank, 2008), which is inclined to spread over the entire economic spectrum. For instance, Silicon Valley in California has ignited an interest in creating Information and Communication Technology (ICT) clusters worldwide. Similar ICT clusters have been introduced in Europe (Hospers, 2005) and developing countries including India (Parthasarathy, 2004) and China (Tan, 2006; Zhou, 2005). Moreover, the trend of cluster development is witnessed in a large variety of industries including finance and producer services (Keeble \& Nachum, 2002; Rosenfeld, 1995, 1997), recreation, culture and media (Hutton, 2006; Mommaas, 2004; Scott, 2004), and e-business (Boasson \& MacPherson, 2001), as well as traditional sectors such as textile, leather, ceramic and furniture industries (Chakravorty, Koo, \& Lall, 2005).

Though not explicitly stated, the literature on cluster development suggests that different clusters are inclined to locate in different parts of a city (Table 1 ). Financial and business clusters are primarily dominant in the central business district (CBD) of a city, not only because of its accessible location and high-quality public facilities but also owing to its proximity to the labour supply, customers and information, as well as the convenience of face-to-face contact in business activities (McCann, 1995; Phelps, 2004). In a large metropolitan region, however, financial and business clusters may spill over into sub-centres, as is the case in London.

Adjacent to universities or research institutes and sometimes distant from the city centre are often places where knowledge clusters emerge. These clusters are usually high-tech and intellectually intensive industries including ICT, biochemistry and pharmaceuticals. Some typical cases are Silicon Valley in the U.S. and the economic clusters around Cambridge and Oxford in the U.K. (Hall, 1997; Saxenian, 1994). Additionally, the significance of knowledge creation and spillover is found to stimulate creative clusters in the inner city, particularly with regard to the media, cultural and design industries (Bathelt, 2005; Hutton, 2004).

In peri-urban areas or new towns, however, manufacturing clusters often proliferate, as a result of the abundant supply of land and cheap labour. Recently, agricultural sectors also have emerged in peri-urban areas, encouraging collaborations between traditional farming, food processing and agricultural tourism to nimbly provide fresh local products as well as recreational services for the local urban markets (Donald \& Blay-Palmer, 2006).

Though distinguishing the characteristics of various clusters still requires effort, many cities have already exhibited an ECfeatured spatial structure (Fig. 1). This structure is somewhat similar to the structure implied by the bid-rent model (Alonso, 1964) in terms of the distribution of different functions. The bid-rent theory postulates that locational choices of individual firms are based on land prices (O'Sullivan, 2000), while cluster analyses are interested in other crucial factors including knowledge transfer, social networks and institutional context, which stimulate the clustering of firms (Phelps, 2004). These factors determine that in the global competition some 'sticky' places are much more effective in attracting firms and businesses (Henry \& Pinch, 2001; Potter \& Watts, 2011). In other words, cluster development generates a 'path' of locational choices for new firms (Arthur, 1994).

In the global market economy, ECs increasingly act as a mechanism that enables concentrations of urban economic activities (Amin \& Thrift, 1992; Lorenzen, 2005; Maskell \& Lorenzen, 2004) and in the meantime shapes the spatial structure of the city. Over time, with changes in the spatial extent of agglomeration, the contribution of particular industrial sectors and the exchange with external economies, the economic geography of a city experiences a dramatic dynamism (Phelps \& Ozawa, 2003). This process, sometimes driven by government interventions, could lead to new urban forms (Walker, 2001).

\section{A bridge between economic and spatial policies: theoretical and policy considerations}

The economic reasons for integrating the EC concept into policies are well articulated and primarily focused on the effects of agglomeration economies and their associated idea supply chains (McDonald, Huang, Tsagdis, \& Tuselmann, 2007), innovation systems (Asheim \& Isaksen, 1997), knowledge spillovers (Bathelt, Malmberg, \& Maskell, 2004), and synergy between firms and/or institutions (Krugman, 1991b; Porter, 1990). If a cluster succeeds in one or more aspects mentioned above, its firms can benefit from increased productivity, reduced costs and improved quality of products (Belussi \& Caldari, 2009). However, the spatial concerns of ECs are quite limited to the establishment of various industrial or business parks to facilitate the geographical proximity of firms, as a condition of the realisation of those effects (Braun \& McHone, 1992; Lai, Peng, Li, \& Lin, 2014).

Aside from creating a favourable geo-setting environment, the spatial concerns of ECs may include the function of ECs and their roles in the spatial structure of a city. Marshall posits that as industrial districts grow, they need more space than what is available at the city centre where land values are high. Consequently, new industrial developments tend to locate on the outskirts of the city or in the surrounding rural areas and towns (Marshall, 1919, p. 285). Black and Henderson (1999) note that the development of clusters has an impact on the restructuring of the urban spatial economy in terms of the increasing mobility of people, labour, and 
Table 1

Spatial-economic characteristics of main economic clusters.

\begin{tabular}{|c|c|c|c|c|c|c|c|}
\hline & Financial clusters & Business clusters & Knowledge clusters & $\begin{array}{l}\text { Recreation } \\
\text { clusters }\end{array}$ & $\begin{array}{l}\text { Manufacturing } \\
\text { clusters }\end{array}$ & $\begin{array}{l}\text { Agriculture } \\
\text { clusters }\end{array}$ & Logistic clusters \\
\hline $\begin{array}{l}\text { Main } \\
\text { agglomeration } \\
\text { factors }\end{array}$ & $\begin{array}{l}\text { Path dependency, } \\
\text { face-to-face } \\
\text { contacts, } \\
\text { favourable } \\
\text { location and } \\
\text { geographical } \\
\text { proximity }\end{array}$ & $\begin{array}{l}\text { Business } \\
\text { competition, face- } \\
\text { to-face contacts, } \\
\text { vibrant business } \\
\text { environment, } \\
\text { favourable location }\end{array}$ & $\begin{array}{l}\text { Knowledge } \\
\text { spillovers, face-to- } \\
\text { face contacts }\end{array}$ & $\begin{array}{l}\text { Social factor, } \\
\text { incl. life style } \\
\text { and culture, } \\
\text { pleasant/ } \\
\text { unique } \\
\text { environment }\end{array}$ & $\begin{array}{l}\text { Industrial traditions } \\
\text { and resource } \\
\text { advantages, global } \\
\text { trade and labour } \\
\text { division, industrial } \\
\text { specialisation }\end{array}$ & $\begin{array}{l}\text { Efficiency of } \\
\text { agricultural } \\
\text { production, } \\
\text { scarcity of } \\
\text { land }\end{array}$ & $\begin{array}{l}\text { Accessibility and } \\
\text { quality of } \\
\text { infrastructure }\end{array}$ \\
\hline $\begin{array}{l}\text { Main economic } \\
\text { activities }\end{array}$ & $\begin{array}{l}\text { Banks, insurance } \\
\text { companies, } \\
\text { financial markets, } \\
\text { accounting } \\
\text { services }\end{array}$ & $\begin{array}{l}\text { Management, } \\
\text { professional, } \\
\text { particularly IT } \\
\text { services, consulting, } \\
\text { advertisement and } \\
\text { media industries }\end{array}$ & $\begin{array}{l}\text { A synergy of } \\
\text { universities and } \\
\text { industries, or } \\
\text { creative services } \\
\text { related to culture } \\
\text { and knowledge }\end{array}$ & $\begin{array}{l}\text { Hotels, } \\
\text { restaurants, } \\
\text { cafes, street } \\
\text { life, nightlife, } \\
\text { and } \\
\text { recreational } \\
\text { shopping }\end{array}$ & $\begin{array}{l}\text { Large scale } \\
\text { production with a } \\
\text { supplicated web of } \\
\text { suppliers and } \\
\text { supporting agencies }\end{array}$ & $\begin{array}{l}\text { An } \\
\text { agricultural } \\
\text { complex with } \\
\text { farming, food } \\
\text { production } \\
\text { and tourism }\end{array}$ & $\begin{array}{l}\text { Multimodal } \\
\text { transport and } \\
\text { distribution } \\
\text { centres of } \\
\text { regional or } \\
\text { national } \\
\text { importance }\end{array}$ \\
\hline Location & City centre & $\begin{array}{l}\text { City centre or sub- } \\
\text { centres }\end{array}$ & $\begin{array}{l}\text { Inner city, edge city } \\
\text { or peri-urban }\end{array}$ & $\begin{array}{l}\text { Inner city, edge } \\
\text { city or peri- } \\
\text { urban }\end{array}$ & $\begin{array}{l}\text { Urban fringe, } \\
\text { transport corridor }\end{array}$ & $\begin{array}{l}\text { Peri-urban or } \\
\text { exurban }\end{array}$ & $\begin{array}{l}\text { Transportation } \\
\text { notes (air, sea, } \\
\text { road, rail) }\end{array}$ \\
\hline $\begin{array}{l}\text { Embedded } \\
\text { linkages with } \\
\text { cities }\end{array}$ & Financial system & $\begin{array}{l}\text { Business } \\
\text { environment, } \\
\text { cooperation of firms }\end{array}$ & $\begin{array}{l}\text { Supportive } \\
\text { institutes and } \\
\text { talent }\end{array}$ & $\begin{array}{l}\text { Convergence of } \\
\text { culture and } \\
\text { (up-) middle } \\
\text { class }\end{array}$ & $\begin{array}{l}\text { Strongly dependent } \\
\text { on the other clusters }\end{array}$ & $\begin{array}{l}\text { Strongly } \\
\text { dependent on } \\
\text { the other } \\
\text { clusters }\end{array}$ & Logistic systems \\
\hline Spatial signatures & City landmarks & $\begin{array}{l}\text { A huge volume of } \\
\text { business and } \\
\text { shopping buildings }\end{array}$ & $\begin{array}{l}\text { Combing with } \\
\text { universities or } \\
\text { institutes, with } \\
\text { high quality } \\
\text { ambience }\end{array}$ & $\begin{array}{l}\text { Stylish, fashion } \\
\text { or picturesque } \\
\text { environment }\end{array}$ & Industrial parks & $\begin{array}{l}\text { Probably } \\
\text { loosely } \\
\text { distributed }\end{array}$ & $\begin{array}{l}\text { Huge transport } \\
\text { infrastructure }\end{array}$ \\
\hline Typical examples & $\begin{array}{l}\text { City of London, } \\
\text { Down- and } \\
\text { Midtown } \\
\text { Manhattan }\end{array}$ & Manhattan & $\begin{array}{l}\text { Silicon Valley, } \\
\text { Route } 128, \text { IT } \\
\text { clusters in } \\
\text { Bangalore and } \\
\text { Beijing }\end{array}$ & $\begin{array}{l}\text { Orlando in } \\
\text { USA, and La } \\
\text { Rambla Street } \\
\text { in Barcelona }\end{array}$ & $\begin{array}{l}\text { Petroleum in Texas, } \\
\text { automobile } \\
\text { manufacturing in } \\
\text { Detroit }\end{array}$ & $\begin{array}{l}\text { Horticulture } \\
\text { in the } \\
\text { Netherlands }\end{array}$ & $\begin{array}{l}\text { Schiphol and } \\
\text { Rotterdam }\end{array}$ \\
\hline
\end{tabular}

knowledge. For instance, the new Third Italian model reflects that clusters could expand from being geographically bounded areas to being part of the regional production organisation, so regional context is important to establish the competitiveness of the clusters as well as their places (Sforzi, 2002), and a multi-cluster platform is perhaps more realistic (Cooke, 2012). It is also argued that at the regional level, economic agglomeration may lead to a relatively more dispersed employment pattern (Gordon \& Richardson, 1996). In addition, Phelps and Ozawa (2003) note agglomeration economies are also featured by pre-industrial, industrial and post-industrial landscapes, which entail new challenges for both economists and geographers.

Owing to economic externalities and spatial spillovers, cluster developments can radically alter a city's land use, traffic flows, property values, environment, and image (Gospodini, 2006). Such processes are evident in London's Barnsbury neighbourhood and New York's Brooklyn Heights neighbourhood, where a supergentrification process is interwoven with the clustering of finance and business services (Butler \& Lees, 2006; Lees, 2003). The clusters in turn generate an affluent middle class, who demand high-quality housing and a lifestyle involving more cultural, leisure and other novel activities (Beriatos \& Gospodini, 2004; Chatterton \& Hollands, 2002; Hollands \& Chatterton, 2003; James, 2005; Mommaas, 2004).

Cluster developments encourage a highly specific territorial process, which performs as an intermediate system between the micro-economy of the commodity-producing society and the structure of the modern space-economy (Scott, 1985). During cluster development, there is a strong incentive to cover the cluster's centre of gravity because of its advantageous spatial accessibility (Scott, 1985). This leads to a landscape of intense concentration of economic activities in the form of functionally specialised districts or quarters (Scott, 1985). The process stimulates population growth and social diversification, drawing massive numbers of people into the functional orbits of the economy and generating increasing demands for working and living spaces (Giuliano, Agarwal, \& Redfearn, 2008; Scott, 1985). A strong skeptical voice in the policy application of the EC is necessary to facilitate the overall urban dynamics, especially in determining the interdependencies among the overall economic performance, the demographic characteristics and the spatial configuration of infrastructures (Martin \& Sunley, 2003).

Urban planning has to respond to these dynamics because economic activities result in certain spatial forms, and the forms, in turn, influence the allocation and organisation of economic activities (Yang, Sliuzas, Cai, \& Ottens, 2012). The inclusion of ECs may cast light on an effective approach to planning the configuration of the urban structure and achieving sustainable economic development. Catering to cluster development, the planning is committed to designating locations for a particular industry to create growth centres in the city as well as sustaining the trend of agglomeration. Such designations and trends could be facilitated by means of taxation, land allocation and the provision of infrastructures. For instance, through institutional interventions, industrial developments characterised by similar and complementary industries are often located together on the fringe of the city (Walker, 2001). The growth of a local labour pool and the improvements of local infrastructure also need to be considered. When the costs reduce the profit margins, clusters can also be relocated to other accessible locations (Scott, 1985). The dynamics of clusters, the transformation and upgrade of their economic activities, the increase in labourers, and the interaction between different land uses together shape the urban form. 


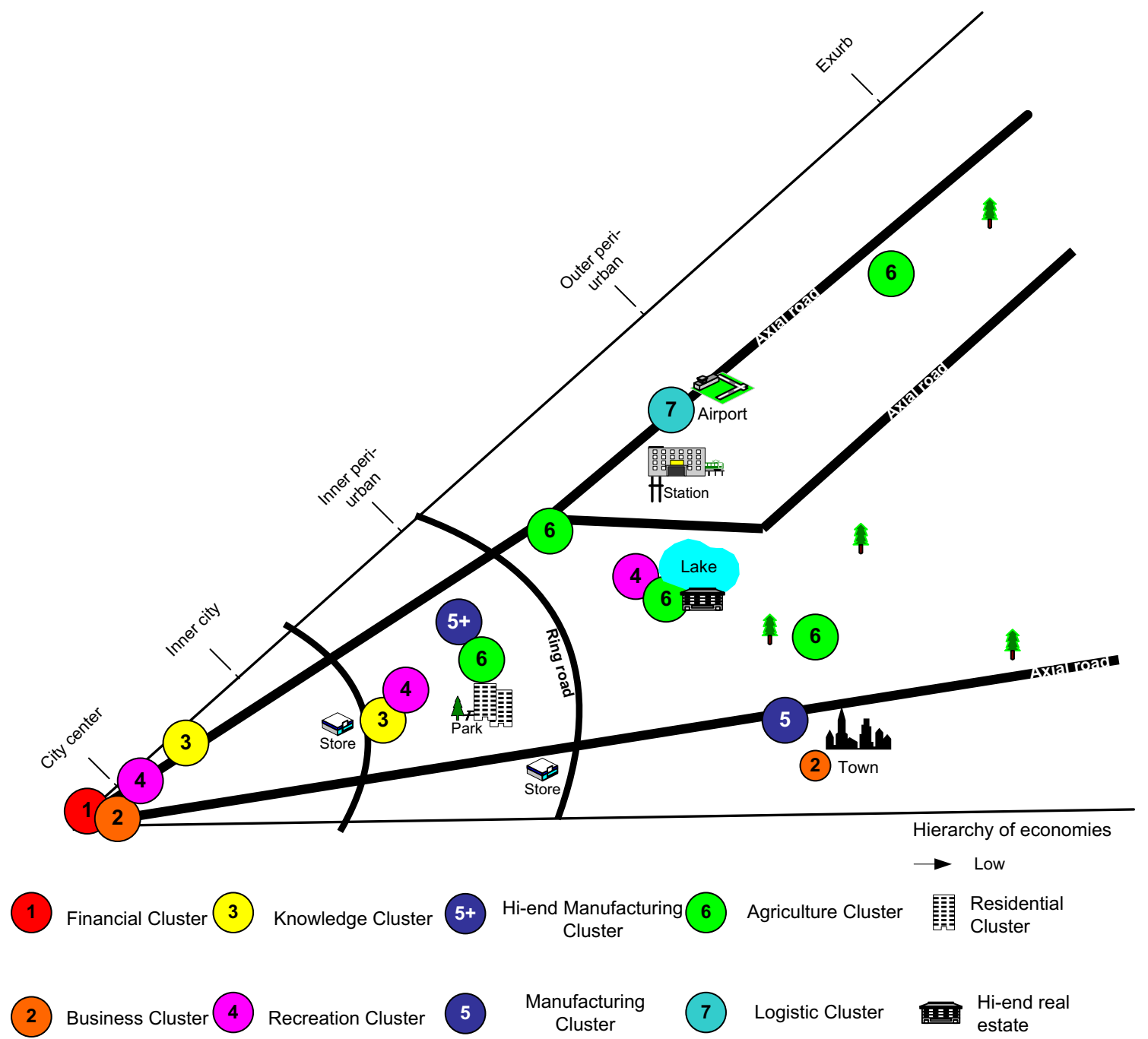

Note: Plots of logistic clusters and settlements do not comply with the hierarchy of economies

Fig. 1. Sketch of economic clusters in a city.

The development of ECs is usually a result of both market mechanisms and policy interventions. The process of clustering and where and how it takes place are analytical questions, while planning is concerned with normative projections of the city the two often not coinciding. Moreover, policy interventions often have unintended effects, leading to more complex challenges for the city. For instance, California's Silicon Valley is notoriously rich in jobs but short on housing, and the Manhattan Central Business Area (CBD) is challenged by the excessive use of private vehicles (Schaller Consulting, 2006). To reduce unintended outcomes in urban development, successful coordination between the economic and spatial policies is indispensable.

As economic and spatial policies work in different domains, the meaning and representation of the cluster concept are different when translated into specific policy devices. The focus of applying the cluster concept also shifts in the different stages of city development. For example, during the era of Marshall's "industrial district", the focus was on reducing production and transportation costs, while in the contemporary globalisation era, the interest has shifted to improving the relative competitiveness of a particular local economy, as in the recent case of Qingdao (Kim, 2010). Understanding such changes should be a prerequisite to investigating the role of ECs in linking economic and spatial policies.
In addition, not all theoretical considerations are well applied to policy making, leaving a large gap for identifying the applications of ECs. Existing policy measures are arguably aimed predominately at localised or place-based economic development, which is derived from localisation economies (Moomaw, 1988; Rosenthal \& Strange, 2004). For example, many industrial parks are established with the purpose of promoting specialisation, division of labour and productivity by means of efficiently using resources (Black \& Henderson, 1999). Factors that can sustain the dynamic growth of clusters, such as the labour pool, information exchange and technical innovation, are raised in regional economic policy (de Miguel Molina, de Miguel Molina, \& Garrigós, 2011); however, these are largely viewed as contextual issues for initiating clusters. Urbanisation economies are generally insufficiently addressed in the current cluster policy application, which is more focused on the overall urban dynamics and the general requirements of firms and people (Feser, 1998; Jacobs, 1984; Rosenthal \& Strange, 2004). The theory of the growth poles also observes that a pole exists not only in the economic space (Perroux, 1955) but also in the geographical space, driving spatial concentration and regional disparities (Parr, 1999). Enlightened by these theoretical and policy concerns, the following section discusses the application of clusters in the spatial policies in Beijing. 


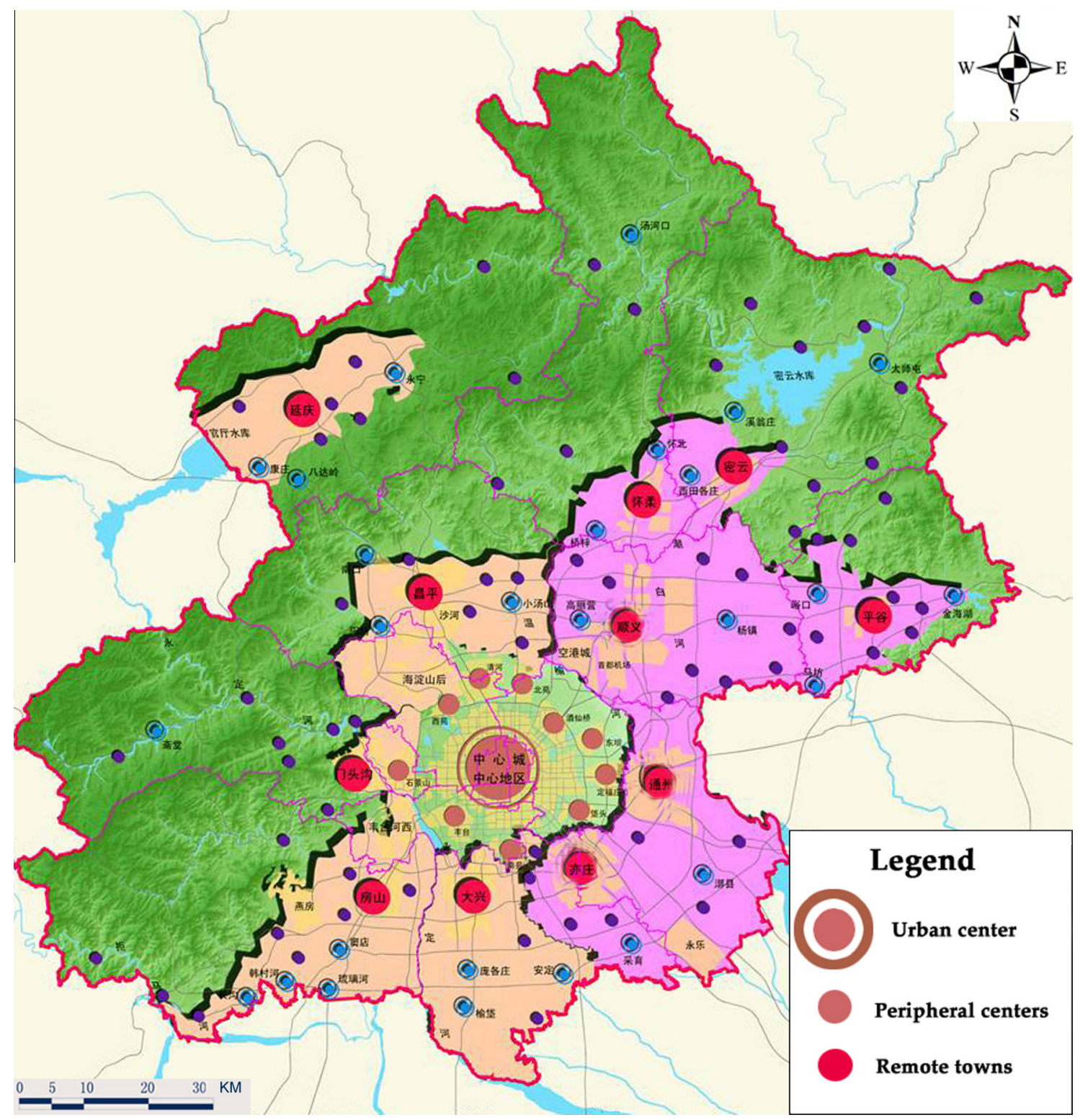

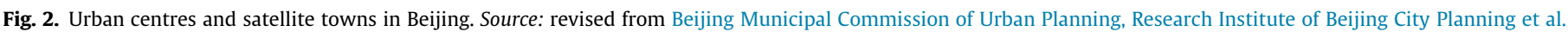
(2007).

\section{Cluster development in Beijing: initiatives in economic and spatial policies}

The Beijing municipality, as of 2012, has a population of 20 million. Its $16,410 \mathrm{~km}^{2}$ of land is administratively divided into 14 urban districts and 2 counties. These divisions are generally classified into four regions: an urban core, an inner-urban area, an outer-urban area and an ex-urban area. The urban core is composed of two traditional urban districts (which were the result of an administrative merger of four districts in 2011).

Cluster-type development, in a broader sense, has been an important element in Beijing's development, in both the periods of the pre-reform planned era and the post-reform market economy. The case of Beijing is illustrated with an emphasis on the role of ECs in economic and spatial policies. By analysing the economic and planning policies and the actual city development in the two periods, this paper provides a new understanding of cluster initiatives and development in different contexts. A large volume of materials was scrutinised, including urban planning documents from the 1980 s to most recently. Interviews were carried out with municipal planners and officials of main industrial parks. The statistical data of economic development and urban construction were examined.

Pre-reform cluster initiatives: the spatial choice to rehabilitate the economy

During the period of the planned economy, the concept of cluster development was to use limited resources to support the economic rehabilitation of disadvantaged urban development. Spatial policies were subordinate to this goal, and the production complex, a soviet-style industrial-residential compound, was adopted as a doctrine for urban spatial organisation. Each of such complexes accommodated a group of firms with similar features in a given area (Gu, Chan, Liu, \& Kesteloot, 2006). This so-called danwei (work unit) system enabled different urban sections to be self-sufficient in working and living (Gaubatz, 1999). 


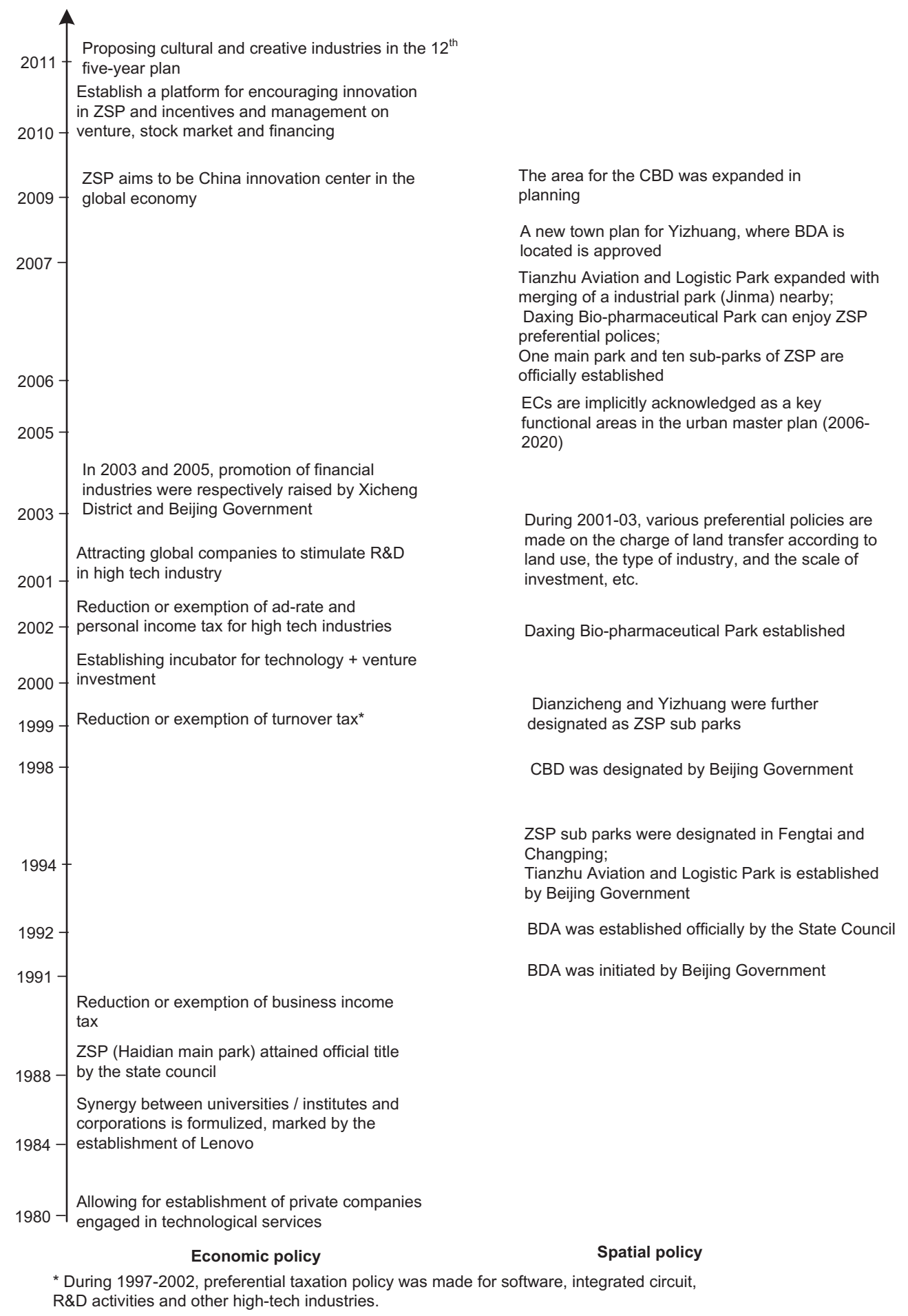

Fig. 3. Main cluster initiatives and measures in economic and spatial policies in Beijing. Source: authors' survey and official documents.

Consequently, urban amenities were for the most part organised around industrial developments.

In the 1950s, six major industrial zones were planned based on the model of residential-industrial complexes. These were steel manufacturing in Shijingshan (West), automobile manufacturing in Fengtai (Southwest), cotton and machinery manufacturing along the Tonghui River (East), electronics for the Jiuxian Bridge (Northeast), chemicals in the south-eastern suburbs, and textile and communication equipment in the northern suburbs (Beijing Municipal Commission of Urban Planning, Research Institute of
Beijing City Planning, \& Association of Beijing City Planning, 2007). These industrial complexes significantly contributed to the rehabilitation of industries and the development of the inner suburban area of Beijing. At the same time, new residential and industrial areas were established in the urban centre, which had accommodated 70\% of new houses by 1962 (Liu, 2004). Heavy investment in transportation and utilities in the inner urban area formed a mono-centric spatial development pattern in Beijing.

With an intention to balance the spatial development over the whole territory, the municipal government started to replicate 
Table 2

Economic performances of manufacturing parks. Data source: Beijing Regional Statistics, 2006 and 2011.

\begin{tabular}{|c|c|c|c|c|c|c|c|}
\hline & \multicolumn{3}{|l|}{2005} & \multicolumn{3}{|l|}{2010} & \multirow{2}{*}{$\begin{array}{l}\text { Compound growth rate, } \\
\text { 2005-2010 (\%) }\end{array}$} \\
\hline & $\begin{array}{l}\text { Industrial } \\
\text { parks }\end{array}$ & $\begin{array}{l}\text { The } \\
\text { municipality }\end{array}$ & $\begin{array}{l}\text { As \% of the } \\
\text { municipality }\end{array}$ & $\begin{array}{l}\text { Industrial } \\
\text { parks }\end{array}$ & $\begin{array}{l}\text { The } \\
\text { municipality }\end{array}$ & $\begin{array}{l}\text { As \% of the } \\
\text { municipality }\end{array}$ & \\
\hline $\begin{array}{l}\text { Accumulated project investment } \\
\text { (RMB, billion) }\end{array}$ & 536.75 & NA & & 825.46 & NA & & 9 \\
\hline $\begin{array}{l}\text { Industrial output value (RMB, } \\
\text { billion) }\end{array}$ & 374.8 & 719.14 & 52 & 616.95 & 1398 & 44 & 10 \\
\hline Accumulated FDI (US\$, billion) & 8.06 & 35.2638 & 23 & 16.93 & 63.6358 & 27 & 16 \\
\hline Tax (RMB, billion) & 22.6 & 100.735 & 22 & 71.3 & 381.091 & 19 & 26 \\
\hline Employment (,000 persons) & 965 & 2311 & 42 & 1466.0 & 2027 & 72 & 9 \\
\hline
\end{tabular}

Table 3

Economic performances of business parks. Data source: Beijing Regional Statistics, 2006 and 2011.

\begin{tabular}{|c|c|c|c|c|c|c|}
\hline & \multicolumn{3}{|l|}{ CBD } & \multicolumn{3}{|c|}{ Financial street district } \\
\hline & 2005 & 2010 & $\begin{array}{l}\text { Compound growth rate, } \\
\text { 2005-2010 (\%) }\end{array}$ & 2005 & 2010 & $\begin{array}{l}\text { Compound growth rate, } \\
2005-2010(\%)\end{array}$ \\
\hline Assets (RMB, billion) & 266 & 1492 & 41 & 6530 & 163,32 & 20 \\
\hline Revenue (RMB, billion) & 86 & 433 & 38 & 106 & 233 & 17 \\
\hline Profit (RMB, billion) & No data & No data & No data & 35.1 & 116.8 & 27 \\
\hline Employment (persons) & 71,923 & 276,989 & 31 & 29,720 & 646,68 & 17 \\
\hline $\begin{array}{l}\% \text { of tertiary employment of the } \\
\text { municipality }\end{array}$ & 1 & 4 & & 1 & 1 & \\
\hline
\end{tabular}

industrial complexes in the outer and ex-urban areas. However, the Cultural Revolution during the 1960s and 70s hampered this attempt and nearly half of the planned projects were left unimplemented.

In the 1990s, a similar scheme was proposed to establish satellite towns including peripheral centres and remote towns (Fig. 2) (Beijing Municipal Commission of Urban Planning et al., 2007). However, with the introduction of an urban land and property market in the 1980s and 1990s, the majority of the residential and industrial developers were inclined to concentrate in the urban centre, to benefit from better access to transport, public facilities and human resources. At the same time, there was a lack of policy incentives to encourage developers to invest in more remote areas. Many of the satellite towns were not full-fledged and did not have the proper infrastructure or adequate amenities, which led to the areas being less attractive for industrial or residential developments.

Current cluster initiatives: economic success with spatial problems

In the transition to a market economy, policy measures have shifted away from a soviet-style planned model. The model of industrial complexes gradually disappeared from policy, and work units were abolished. Nearly all urban functions were gradually configured by market mechanisms.

In the process of Beijing's market transition, cluster development was first initiated by the economic plan of the establishment of the Zhongguancun Science Park (ZSP) in 1988 (Wang \& Wang, 1998) (Fig. 3). The ZSP was initially known for being a commercial area that sold imported information and technology (IT) products at the beginning of China's economic liberalisation. The same district was home to several leading universities and research institutes including the Chinese Academy of Sciences (CAS), Beijing University and Tsinghua University. The transformation of the ZSP was initiated by a number of state-owned research institutions through the marketisation of technology, such as IT. A typical

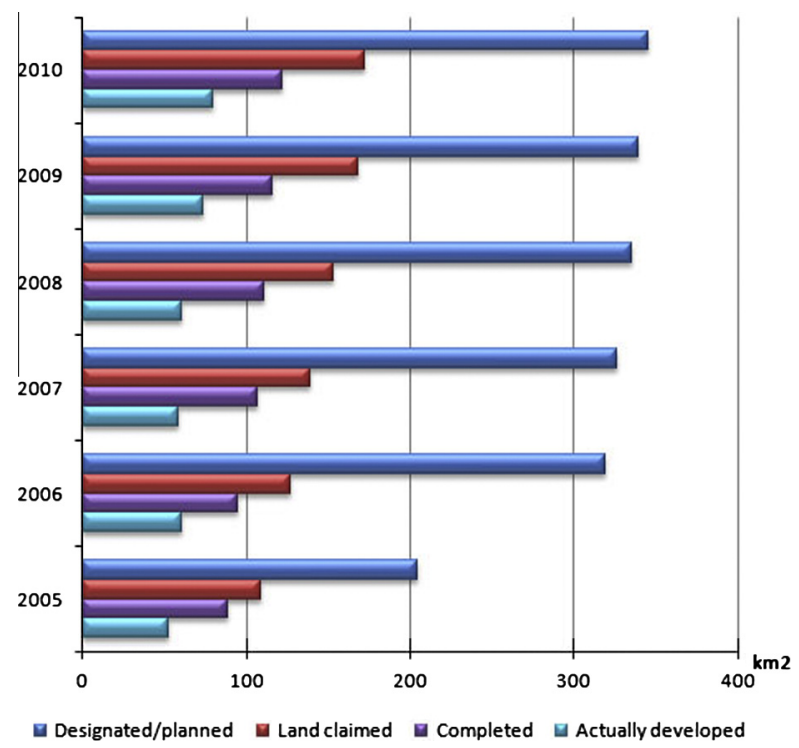

Fig. 4. Land development of industrial parks in Beijing during 2005-2010. Data source: Beijing Regional Statistics, 2006 and 2011.

example is the Chinese Academy of Sciences (CAS)-affiliated Lenovo, founded in 1984. Cluster initiatives were put on the agenda with the establishment of the ZSP in 1988 by the State Council as the first high-tech industrial park in China. A major purpose of the ZSP was to experiment with proper ways to facilitate high-tech industries in China's market transition. Government interventions strongly supported the development of an IT cluster by removing institutional barriers, such as the constraints on private investment and the mobility of labours among firms. The ZSP soon attracted global attention and accommodated many multinational companies such as IBM, Microsoft, Intel and many other large IT manufacturers. Policies also stimulated the park to 


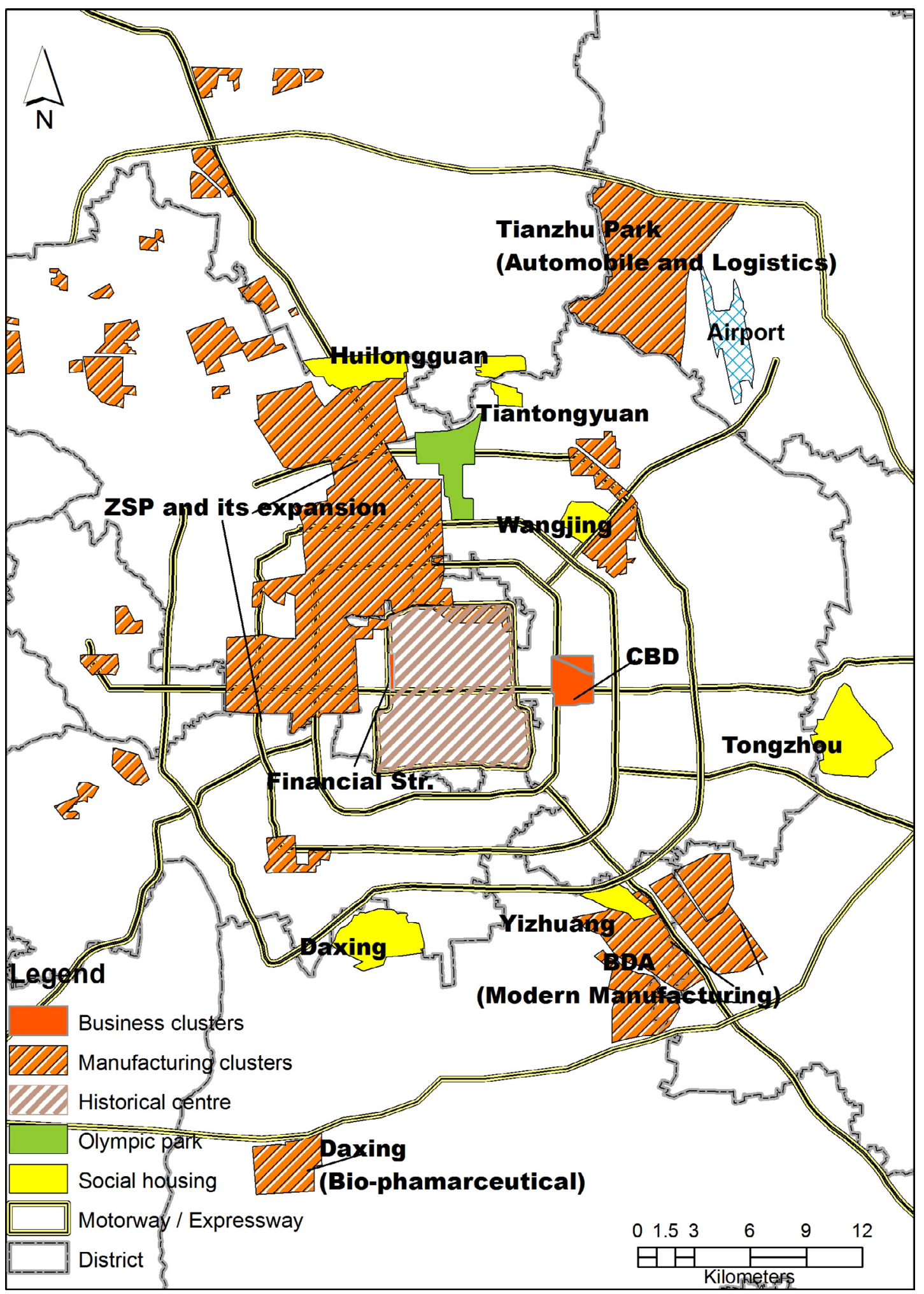

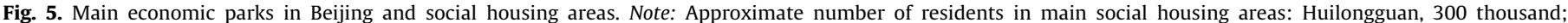
Tiantongyuan, 300 thousand; Wangjing, 300 thousand; Tongzhou, planned 900 thousand; Yizhuang, planned 800 thousand; Daxing, planned $600-700$ thousand.

transform from retail and the manufacture of IT products to the research and design of such products. Moreover, firms were encouraged to target the global market. In 2009, the ZSP was positioned by the government as a key innovation centre of industrial development, with a clear vision to pioneer China's transformation from a "world factory" to an industrial innovation centre.
After the success of the ZSP, Beijing built several industrial parks, aimed at stimulating industrial development in the form of ECs. During the period 1994-2006, the ZSP expanded with ten sub-parks designated by the government. In addition, the Beijing Economic and Technology Developmental Area (BDA) was established for developing equipment manufacturing, electronics and 
Table 4

Policy instruments, agglomeration economies and cluster development during the market economy in Beijing. Source: according to the survey of the authors.

\begin{tabular}{|c|c|c|c|c|}
\hline Policy instruments & Main content & Type of policy & Roles in cluster development & $\begin{array}{l}\text { Type of } \\
\text { agglomeration } \\
\text { economies }\end{array}$ \\
\hline Allocating special area & Establishing industrial and business parks & $\begin{array}{l}\text { Economic and spatial } \\
\text { policy }\end{array}$ & $\begin{array}{l}\text { Facilitating economic } \\
\text { incentives and fostering } \\
\text { agglomeration }\end{array}$ & $\begin{array}{l}\text { Localisation } \\
\text { economies }\end{array}$ \\
\hline Preferable taxation & $\begin{array}{l}\text { Wavier or reduction of taxation on firms of certain sectors } \\
\text { and/or at initial stages }\end{array}$ & Economic policy & Promoting investment & $\begin{array}{l}\text { Urbanisation } \\
\text { and } \\
\text { localisation } \\
\text { economies }\end{array}$ \\
\hline Preferable land supply & Wavier or reduction of land use fees & $\begin{array}{l}\text { Spatial policy for firms } \\
\text { located in particular } \\
\text { area }\end{array}$ & $\begin{array}{l}\text { Promoting industrial } \\
\text { investment }\end{array}$ & $\begin{array}{l}\text { Localisation } \\
\text { economies }\end{array}$ \\
\hline Talent scheme & $\begin{array}{l}\text { Reduction of income tax; preferable immigration policy for } \\
\text { overseas Chinese and foreigners; various benefits for family } \\
\text { members such as schooling for children }\end{array}$ & Economic policy & $\begin{array}{l}\text { Generating an intelligent } \\
\text { labour force }\end{array}$ & $\begin{array}{l}\text { Urbanisation } \\
\text { economies }\end{array}$ \\
\hline Planning permit & One-stop services for approval of location & $\begin{array}{l}\text { Economic and spatial } \\
\text { policy for firms located } \\
\text { in particular parks }\end{array}$ & $\begin{array}{l}\text { Promoting establishment of } \\
\text { firms }\end{array}$ & $\begin{array}{l}\text { Localisation } \\
\text { economies }\end{array}$ \\
\hline Incubator & $\begin{array}{l}\text { Establishing a linkage between firms and universities; } \\
\text { providing technical assistance; offering office areas; } \\
\text { encouraging knowledge exchange between firms; providing } \\
\text { venture capital }\end{array}$ & $\begin{array}{l}\text { Economic and } \\
\text { administrative policy } \\
\text { for parks }\end{array}$ & $\begin{array}{l}\text { Knowledge support, and } \\
\text { capital support for start-up } \\
\text { companies }\end{array}$ & $\begin{array}{l}\text { Localisation } \\
\text { economies }\end{array}$ \\
\hline $\begin{array}{l}\text { Promoting high-tech } \\
\text { industries }\end{array}$ & $\begin{array}{l}\text { Providing favourable land and taxation policies, simplified } \\
\text { land supply procedure and administration }\end{array}$ & $\begin{array}{l}\text { Economic and } \\
\text { administrative policy }\end{array}$ & $\begin{array}{l}\text { Providing long-term benefits } \\
\text { for high-tech investments }\end{array}$ & $\begin{array}{l}\text { Urbanisation } \\
\text { economies }\end{array}$ \\
\hline $\begin{array}{l}\text { Supporting } \\
\quad \text { organizations }\end{array}$ & $\begin{array}{l}\text { Establishing industrial association, intellectual property } \\
\text { management office and technology transfer commission }\end{array}$ & Economic policy & $\begin{array}{l}\text { Facilitating industrial } \\
\text { development }\end{array}$ & $\begin{array}{l}\text { Urbanisation } \\
\text { economies }\end{array}$ \\
\hline Promoting a global city & $\begin{array}{l}\text { Comprehensive development plans to promote Beijing's } \\
\text { international status }\end{array}$ & $\begin{array}{l}\text { Economic and spatial } \\
\text { policies }\end{array}$ & $\begin{array}{l}\text { Improving the images of the } \\
\text { city and firms, and promoting } \\
\text { global competitiveness }\end{array}$ & $\begin{array}{l}\text { Urbanisation } \\
\text { economies }\end{array}$ \\
\hline $\begin{array}{l}\text { Infrastructure } \\
\text { construction }\end{array}$ & $\begin{array}{l}\text { Multiple large municipal infrastructure projects such as new } \\
\text { metro lines, airport and train station }\end{array}$ & Spatial policy & $\begin{array}{l}\text { Improving urban } \\
\text { infrastructure and public } \\
\text { services }\end{array}$ & $\begin{array}{l}\text { Urbanisation } \\
\text { and } \\
\text { localisation } \\
\text { economies }\end{array}$ \\
\hline
\end{tabular}

bio-pharmaceuticals; Tianzhu Park was developed for accommodating logistic and automobile manufacturing; and a biopharmaceutical park was established in Daxing. These three parks gradually obtained national significance and started to share the same preferential policy as the ZSP. In addition, a Central Business District (CBD) was created along the east 3rd ring road. In the meantime, based on the agglomeration of many domestic banks, a Financial Street (FS) emerged between the 2nd and 3rd ring roads in West Beijing.

The establishment of these parks is clearly in line with the new trends of worldwide industrial development. In addition to IT clusters, other high-tech industrial clusters such as biopharmaceuticals have also been promoted, resulting in new industrial spaces. In 2011, a cultural and creative cluster was introduced in Beijing's 12th five-year plan, reflecting the city's new development prospects of establishing a competitive cultural and creative economy. Consequently, a large culture and multimedia complex was planned in Tongzhou. In addition, a new energy cluster will be built in Miyun County, and the expansion of the Financial Street is under preparation.

In general, ECs have contributed significantly to the economic growth of the city. As Table 2 indicates, industrial activities are concentrated in industrial parks, which have become the new engine of manufacturing growth in the city. During the period 2005-2010, the industrial output of all industrial parks accounted for approximately half of the total industrial output of the municipality (RMB 617 billion out of RMB 1398 billion in 2010). At the same time, the employment of the industrial sector decreased; however, the employment of industrial parks increased by $9 \%$ annually. Today, industrial parks contributed to approximately $20 \%$ of the municipal tax, and its value tripled over the last 5 years. Industrial parks have also become a main destination for FDI, facilitating 27\% of Beijing's total FDI in 2010.
For business parks, a similar trend is prominent. The CBD and Financial Street have grown rapidly, as evidenced by the significant increase of main indicators (Table 3). In particular, employment in the CBD had increased 31\% annually from 2005 to 2010. Its contribution to the tertiary industry of the whole municipality rose from $1 \%$ in 2005 to $4 \%$ in 2010. Much of the increase came from high-end service sectors.

Despite the economic success, the rapid growth of ECs is the cause of many problems. For instance, land was often abused in the name of EC development. In 2003 alone, some 470 parks were built, many of which were small or medium sized but had no clear vision for development. Circa 2006, only 19 manufacturing parks were officially recognised by the municipal government, while all others were closed. Moreover, a large amount of land was not properly positioned or developed. In $2005,81 \%$ of claimed land was equipped with basic infrastructure and facilities and ready to be leased. In 2010 , the figure decreased to $71 \%$, with only $46 \%$ actually developed (Fig. 4). The oversupply of land reflects the city's eagerness to promote economic growth with EC development. However, a lack of careful planning led to a failure in coordinating spatial measures with economic performance.

In addition, the development of ECs gave rise to a series of spatial problems related to the urban structure. As Fig. 5 indicates, the majority of industrial and business parks are concentrated in and around the urban centre. This makes the urban centre successful and attractive; however, the centre has become overwhelmingly dominated by high-end commercial and real estate development. The urban centre, therefore, does not offer a sufficient amount of affordable housing for low- and middle-income groups who are an important labour force for the industrial and business parks. More affordable housing is generally provided in suburban areas (Fig. 5). For example, more than 300,000 people live in Tiantongyuan, one of the major neighbourhoods designated 


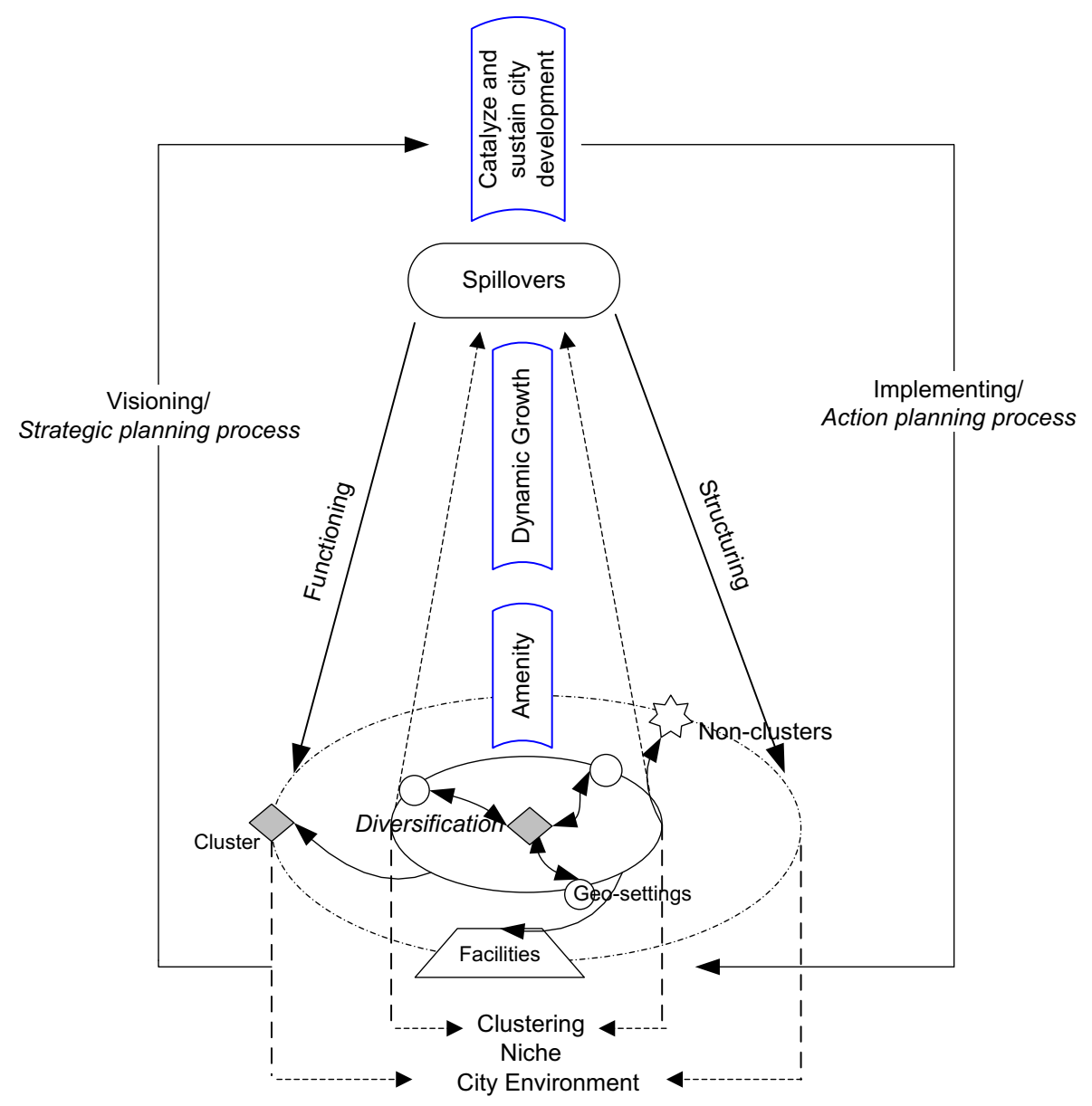

Fig. 6. Spatial planning approach based on economic clusters.

as social housing. The commuting from the residents creates congestion every day, especially at peak hours. Opened in 2007, the No. 5 Metro Line established a link between Tiantongyuan and the $\mathrm{CBD}$, which enabled 706,000 passenger-trips during its first $27 \mathrm{~h}$ in operation. ${ }^{2}$ Similarly, in many other places, long-distance commuting is still an inevitable part of people's daily life (Feng, Dijst, Prillwitz, \& Wissink, 2013). As reported recently, on average, people living and working in Beijing have to spend 52 min commuting each day (Chinese Academy of Sciences, 2010).

\section{Policy incentives and two types of agglomeration economies}

The cluster development in Beijing has been strongly influenced by policy. In the planned era, attention was only given to development in specific areas to achieve the rapid recovery of certain industries. Ignorance of other factors, such as technology and talent, and the influence of urban development lead to the failure of this model in the designated areas.

After the economic reform and during the modern cluster development, the policy instruments have become more comprehensive, and more interactions between economic and spatial policies are promoted (Table 4). The industrial and business parks act as a platform to carry out both economic and spatial policy incentives, which makes the process of attracting firms and therefore the establishment of the clusters easier by removing institutional barriers or by testing new instruments in certain

\footnotetext{
2 The survey was carried out during $14-23$ h on 7 October 2007 and 5-23 h on 8 October 2007, see http://news.xinhuanet.com/newscenter/2007-10/10/content_6855037.htm (last access on September 9th of 2012).
}

areas. Some policy instruments pay special attention to the initial phase of cluster development including preferable taxation and land supply, business attraction, and incubators, while other policy instruments have an effect on the long term including, for example, the industrial development and promotion platform, which focuses on facilitating communication among firms and protecting intellectual property. Some instruments may only contribute to localisation economies such as the establishment of industrial and business parks; some have an effect on the urbanisation economies, for example, in attracting talent, and others work well in the effects of both localisation and urbanisation economies, for example, in the construction of metro lines. These two types of agglomeration economies can be mutually influenced. In particular, urbanisation economies, with the increasing importance of talent, knowledge and long-term policy effects, have a more important role in cluster development. With the continual expansion of economic parks and the construction of new parks, localisation economies can be scaled up to the city level. These complex interactions of policy effects and ensuing spatial problems require more deliberation in urban planning.

\section{Connecting economic and spatial policies}

\section{A cluster-based spatial approach to urban development}

A cluster-based spatial approach, which works at two levels, can be useful for urban development (Fig. 6). At the local level, planners should first identify the roles and characteristics of different areas and prioritise the places with the potential to transfer local comparative advantages into competitive strengths. 


\begin{tabular}{|c|c|c|}
\hline & Economic policy & Spatial policy \\
\hline $\begin{array}{l}\text { Economic } \\
\text { Attributes }\end{array}$ & $\begin{array}{l}\text { Sector-based } \\
\text { - Hierarchical planning procedure } \\
\text { - Industrial chain for particular industry } \\
\text { Improve economic growth } \\
\text { and sustainability with } \\
\text { financial incentives }\end{array}$ & $\begin{array}{l}\text { A group of firms } \\
\text {-With potential or engaged in } \\
\text { similar industries } \\
\text {-Mixed industrial structure } \\
\text {-Services, utilities and infrastructures } \\
\text { Improve spatial growth and } \\
\text { sustainability with land and } \\
\text { facility arrangements }\end{array}$ \\
\hline $\begin{array}{c}\text { Spatial } \\
\text { Attributes }\end{array}$ & $\begin{array}{c}\text { Industrial allocation } \\
\text { As place }\end{array}$ & $\begin{array}{l}\text { Spatial organisation } \\
\text { As space or a place in } \\
\text { urban structure }\end{array}$ \\
\hline
\end{tabular}

Fig. 7. Connections and differences of cluster ideas in economic and spatial plans.

Factors of consideration mainly include the historical development of the area, the urban activities of the neighbourhood, land availability, and accessibility to other main urban nodes. For instance, the ZSP is in the university district of the city, and the CBD area used to be a commercial area and is close to the capital's first embassy district. The FS has a concentration of approximately $90 \%$ of the headquarters of China's large domestic banks.

The actual development of ECs depends on the coordination between the spatial clustering of industries and the regional specialisation (Krugman, 1991a). Urban planning can help create this coordination by allocating land, transport and public facilities in the desired locations with proper quality. To illustrate this, an interesting case is BDA. Though initiated in 1991, only after the proposal of designating BDA as an important functional area in Beijing's most recent Master Plan (2004-2020) did BDA start to receive attention for business investment. The earlier stagnancy of BDA was primarily because urban development had been predominately emphasising the ICT industries and industrial parks such as the ZSP. In contrast, the success of the ZSP reflects that urban planning should respect and consolidate spontaneous clustering processes and in the meantime avoid creating new rivals because assigning the same function to different parks might dilute the strength of both parks. For example, the establishment of the Daxing Pharmaceutical Park, which promotes similar sectors as BDA, detracts strength and capacity from both parks.

The role of spatial measures is to create an environment that accommodates firms and attracts associated agencies and labourers. The establishment of various economic parks in Beijing and many other cities in China is to provide such an environment. In addition to negotiable land lease prices, ${ }^{3}$ other incentives include the provision of cleared land with basic infrastructure including electricity, water, gas and transport and telecommunication connections, which are favourable for investors.

However, inadequate attention is paid to improving the spatial quality of the industrial environment, especially in accordance with the urban environment at large. This is an uneasy task, as the desired quality of the space depends on the type of economic activities, the development stage of firms, and the specific requirements of firms. For instance, the ZSP in its early stages was a retail street specialising in electronics and computers. It grew quickly

\footnotetext{
3 Before 2006, to attract investors, industrial land was usually leased at very low prices or even at no cost.
}

into an urban node where the old retail environment was not compatible with the upgrading of the economic activities such as new R\&D firms and multinational corporations. Catering for the demand, a spacious campus with high-quality facilities was established to provide a better business environment. Nevertheless, severe traffic congestion occurred in the ZSP area.

Despite the fact that different clusters often have different requirements for the spatial environment, urban planning is expected to work with the factors that encourage and facilitate spatial agglomeration and spin-offs of firms and contribute to increasing economic returns. For instance, the convenience of face-to-face contact and public amenities for workers are important factors. To a large extent, these factors are still important for knowledge-based and innovation-driven economies.

Another important aspect that concerns the development of a cluster environment is to create a diversified urban space to enable dynamic interactions. Unlike economic measures, which usually encourage specialisation in cluster development by extending the industrial chains and innovation processes, spatial polices can efficiently enhance functional diversity by means of arranging different facilities. Such diversity could enable the city to enhance innovation and production (George, 1972). For large cities, such effects are more salient, which may be leveraged by their dense transport networks, good access to global markets, and convenient amenities (Giuliano et al., 2008; Richardson, 2003). For instance, the CBD of Beijing used to be a pure business zone with concrete and steel office towers but few social and recreational facilities. Many recreational facilities were built within the area to change this image, such as the World Trade Plaza (shi mao tian jie), which provides shopping, entertainment and catering services in a stylish and pleasant recreational environment.

At the city or regional scale, ECs can be employed as an instrument to arrange capital, people and traffic to shape urban spatial development. The fast growth of the ZSP drives the city to grow towards the northwest. Together with the university district, which is also concentrated in the north, it is thus difficult to balance the development between the south and the north of the city. Moreover, the concentration of ECs in the urban centre has reinforced the mono-centric pattern of the city, leading to serious traffic congestion and air pollution (Yang et al., 2013). In the meantime, ECs may have externalities affecting non-cluster activities. For instance, with the development of the ZSP, IT activities spilled over nearly the whole urban centre and expelled many other traditional businesses. 


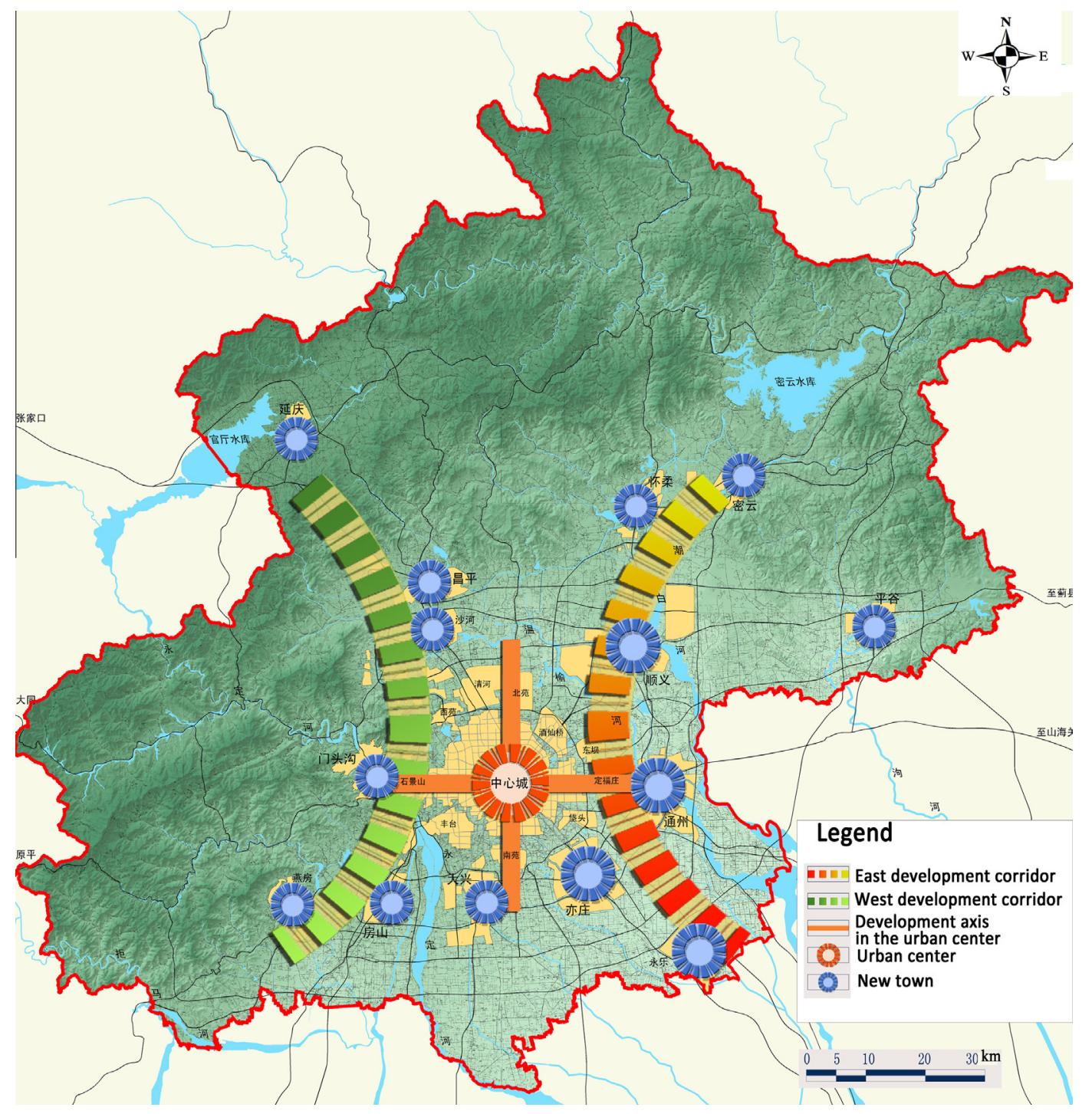

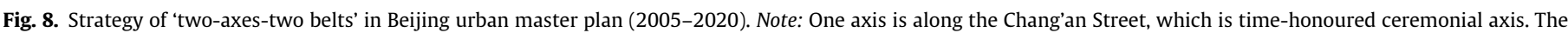

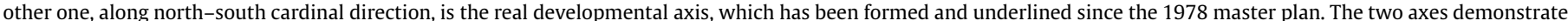

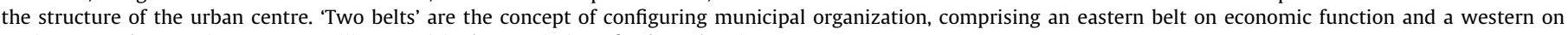
environmental protection. Source: Beijing Municipal Commission of Urban Planning.

Overlooking the potential spatial and environmental impacts of ECs can lead to unsustainable urban development. Current traffic problems in Beijing are largely due to extensive spatial separation between working and residential functions (Fig. 5), while the public transport linkages between these functions are inadequate. Because traffic demand generated by the growth of ECs such as the ZSP and the CBD was largely underestimated and overlooked in the beginning, the later performance of the ECs and urban areas is significantly constrained.

Economic clusters as a connection between economic and spatial polices

In terms of the application of ECs, the connections are demonstrated between the current economic and spatial plans of Beijing, while many mismatches or contradictions also exist (Fig. 7). In economic policy, the concept of clusters is mostly sectorbased and largely decided according to the output or employment of a collection of industries. It signifies a core industry, while other industries perform a supporting role. The master economic policy at the municipal level is a type of development planning. It concerns aspects of economic development including the resources, the social and economic conditions, the comparative advantages and the challenges regarding the ability to predict and guide future economic development. In the 11th five-year plan for Beijing, the main goal of economic development is to make Beijing into a global city. To this end, high-end service economies are prioritised and sectors such as the finance, business, information and communication and knowledge industries are emphasised (Beijing Development, 2006; Beijing Industrial Development Bureau, 2006, 2007).

It should be noted that sector-based clusters are different from key or pillar industries, which are often criticised for having become a somewhat winner-selection type of development planning (Desrochers, 2004). Other than for improving the existing economic strength, the cluster concept is employed to catalyse the developmental potential of newly emerged industries, such as the cultural industry. However, recently devised clusters are highly focused on one particular industry and place less emphasis on the relations between different industries or the internal structure of each industry. 


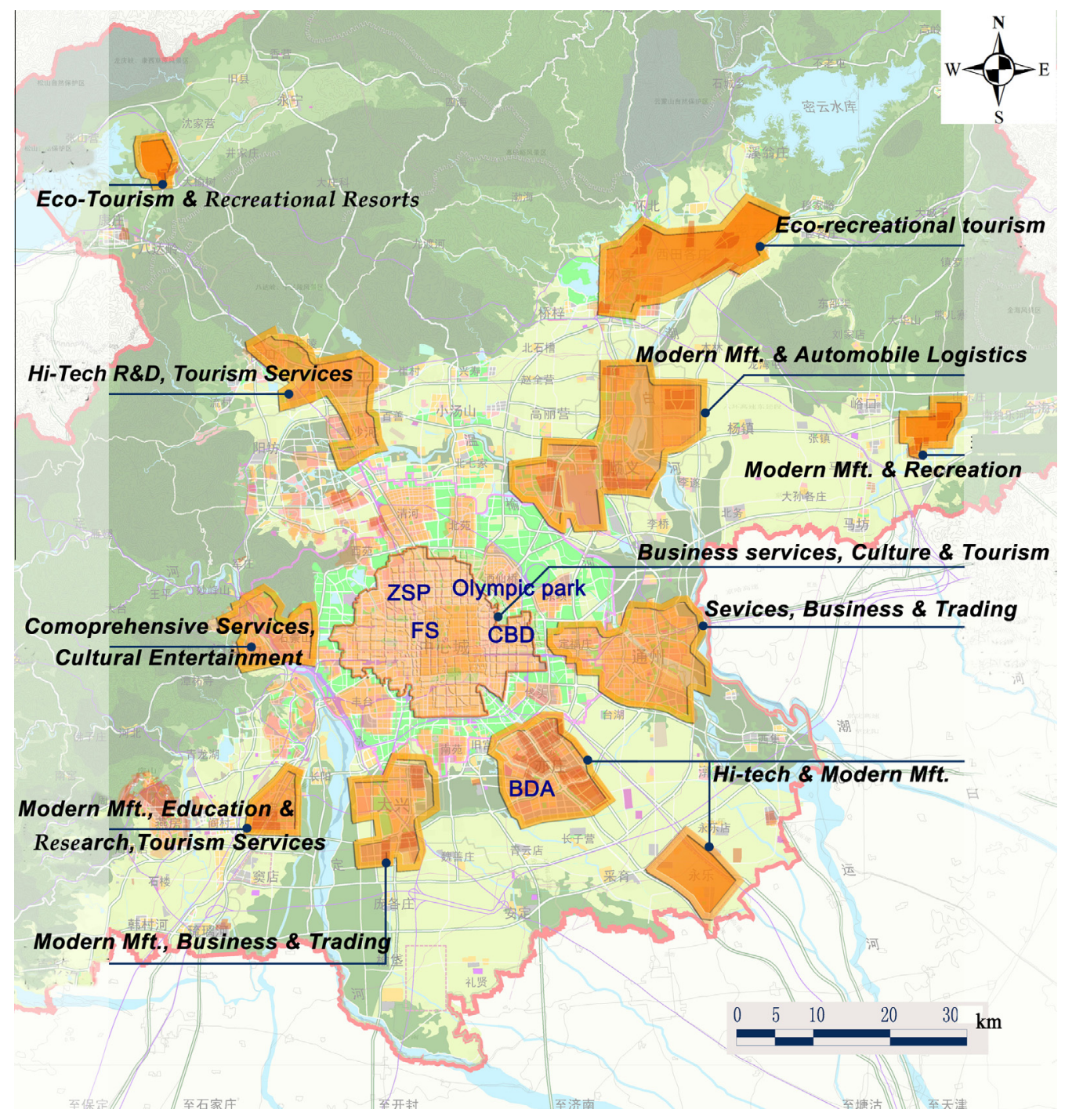

Fig. 9. Conception of 'multi-centres' in Beijing urban master plan (2005-2020). Source: Beijing Municipal Commission of Urban Planning.

Unlike economic policies that treat a cluster as a bundle of economic activities, urban planning regards it as a space with a certain arrangement of land, transport, infrastructure and public facilities. To make an integrated economic and spatial plan for ECs, a fundamental challenge is coordinating the cluster identification, which is not only a task of recognising the particular industries in economic policy but also a task of recognising a collection of firms and their spatial configuration in planning.

Urban planning can treat ECs as places to accommodate urban functions to shape the urban spatial structure. A major spatial designation introduced in the Beijing master plan (2004-2020) is an urban spatial structure characterised by 'two axes, two corridors and multiple centres' (Fig. 8) (Beijing Municipal Commission of Urban Planning, 2005). The multiple centres, located in the developmental axes and corridors, include not only the existing and emerging economic areas, such as the ZSP, CBD and the Olympic Park (Zhang \& Zhao, 2009), but also many newly proposed centres (see Fig. 9). This plan aims to transform Beijing's spatial structure from mono-centric to polycentric. Given the lessons of the construction of satellite towns in the 1960s and 70s, spatial plans have to coordinate with economic plans to function in space. However, not all planned centres have a clear vision in terms of economic growth, leading to spatial uncertainties in the creation of these multiple centres.

\section{Conclusions}

Cluster development increasingly shapes the economic geography of contemporary cities. Aiming to contribute to the improvement of urban spatial structure and economic growth, this paper explores the roles of ECs as a bridge between spatial and economic policies. The practice of employing ECs to link the two policy domains is illustrated by a number of cluster-featured urban development cases. Theoretically, EC use is backed by agglomeration economies, including urbanisation economies, spillovers, increasing returns to scale, and diversified urban economies.

The case of Beijing demonstrates the interaction between economic and spatial policies in the Chinese context, given that strong agglomeration forces favour economic activity in this large capital city. It highlights that cluster policy can foster localisation and urbanisation economies, from which closer local economic ties may emerge. Nevertheless, the insufficiency of spatial policies in the intervening cluster development is apparent. This can be explained by the fact that spatial policies are often subordinate to economic purposes and designations in the planning process. As a result, a lack of understanding of the spatial effects of concentrated industrial complexes leads to a mono-centric urban structure, and the ignorance of the economic potential of designated spaces results in the failure of the satellite town's programme. 
Moreover, the continuing growth of economic clusters and the ineffective interventions of spatial policies in managing the clusters contribute to unexpected housing shortages and traffic congestion. The experience of Beijing indicates that the influence of cluster development should be considered in both the economic and spatial policies at all stages of city development.

Based on the case studies in Beijing, it is proposed that ECs be incorporated into urban planning at two levels. At the local level, the site suitability and environmental quality/impact for cluster development should be concerned, while at the city level, a concordant relationship between cluster development and the overall urban spatial structure should be a major goal. As clusters of different natures demand varying development conditions, every specific case deserves dedicated analyses of land use, transportation, employment, housing, and cluster vis-à-vis noncluster-based economic activities. Consequently, social and economic objectives and spatial prospects can be better linked with planning parameters. This approach could contribute to urban planning practices by enabling more effective coordination between economic growth and urban spatial development. For China and other developing countries, such an improvement should contribute to achieving both economic and spatial development goals.

\section{Acknowledgements}

We would like to thank the editor and two anonymous reviewers for their valuable comments. This research is supported by National Science Foundation of China (NSFC Grant Number: 41371008).

\section{References}

Alonso, W. (1964). Location and land use: Toward a general theory of land rent. Cambridge: Harvard University Press.

Amin, A., \& Thrift, N. (1992). Neo-Marshallian nodes in global networks. International Journal of Urban and Regional Research, 16, 571-587.

Arthur, W. B. (1994). Increasing returns and path dependence in the economy. Ann Arbor: University of Michigan Press.

Asheim, B., \& Isaksen, A. (1997). Location, agglomeration and innovation: Towards regional innovation systems in Norway? European Planning Studies, 5, 299-330.

Atherton, A. (2003). Examining clusters formation from the 'bottom-up': Analysis of four cases in the north of England. Environment and Planning $C$ - Government and Policy, 21, 21-35.

Audirac, I. (2003). Information-age landscapes outside the developed world: Bangalore, India, and Guadalajara, Mexico. Journal of the American Planning Association, 69, 16-32.

Bathelt, H. (2005). Cluster relations in the media industry: Exploring the 'distanced neighbour' paradox in Leipzig. Regional Studies, 39, 105-127.

Bathelt, H., Malmberg, A., \& Maskell, P. (2004). Clusters and knowledge: Local buzz, global pipelines and the process of knowledge creation. Progress in Human Geography, 28, 31-56.

Beijing Development and Reform Commission (2006). Beijing service economy plan in the 11-5th year period.

Beijing Industrial Development Bureau (2006). Beijing industrial plan in the 11-5th year period.

Beijing Industrial Development Bureau (2007). Automobile base in Beijing.

Beijing Municipal Commission of Urban Planning (2005). Beijing master urban plan for 2004-2020. Beijing.

Beijing Municipal Commission of Urban Planning, Research Institute of Beijing City Planning, \& Association of Beijing City Planning (2007). Compile of Beijing city plan, 1949-2005.

Belussi, F., \& Caldari, K. (2009). At the origin of the industrial district: Alfred Marshall and the Cambridge school. Cambridge Journal of Economics, 33, 335-355.

Bergman, E. M., \& Feser, E. J. (1999). Industrial and regional clusters: Concepts and comparative applications. In S. Loveridge (Ed.), The web book of regional science. West Virginia University.

Beriatos, E., \& Gospodini, A. (2004). ‘Glocalising' urban landscapes: Athens and the 2004 Olympics. Cities, 21, 187-202.

Black, D., \& Henderson, V. (1999). A theory of urban growth. Journal of Political Economy, 107, 252-284.

Boasson, V., \& MacPherson, A. (2001). The role of geographic location in the financial and innovation performance of publicly traded pharmaceutical companies: Empirical evidence from the United States. Environment and Planning A, 33, 1431-1444.
Braun, B. M., \& McHone, W. (1992). Science parks as economic development policy: A case study approach. Economic Development Quarterly, 5, 135-147.

Broll, U., \& Roldán-Ponce, A. (2011). Clustering in Dresden. European Planning Studies, 19, 949-965.

Butler, T., \& Lees, L. (2006). Super-gentrification in Barnsbury, London: Globalization and gentrifying global elites at the neighbourhood level. Transactions of the Institute of British Geographers, 31, 467-487.

Chakravorty, S., Koo, J., \& Lall, S. V. (2005). Do localization economies matter in cluster formation? Questioning the conventional wisdom with data from Indian metropolises. Environment and Planning A, 37, 331-353.

Chatterton, P., \& Hollands, R. (2002). Theorising urban playscapes: Producing, regulating and consuming youthful nightlife city spaces. Urban Studies, 39, 95-116.

Chinese Academy of Sciences (2010). The new urbanisation road in China, 2010 report. Beijing: Science Press (in Chinese).

Cooke, P. (2012). From clusters to platform policies in regional development European Planning Studies, 20, 1415-1424.

Cortright, J. (2006). Making sense of clusters: Regional competitiveness and economic development. A discussion paper prepared for the Brookings institution metropolitan policy program (Vol. 2006, pp. 58-62). Washington, DC: Brookings Institution.

de Miguel Molina, B., de Miguel Molina, M., \& Garrigós, J. A. (2011). The innovative regional environment and the dynamics of its clusters. European Planning Studies, 19, 1713-1733.

Desrochers, P. (2004). Cluster-based economic strategy, facilitation policy and the market process. The Review of Austrian Economics, 17, 233-245.

Donald, B., \& Blay-Palmer, A. (2006). The urban creative-food economy: Producing food for the urban elite or social inclusion opportunity? Environment and Planning A, 38, 1901-1920.

Feng, J., Dijst, M., Prillwitz, J., \& Wissink, B. (2013). Travel time and distance in international perspective: A comparison between Nanjing (China) and the Randstad (The Netherlands). Urban Studies, 50, 2993-3010.

Feser, E. J. (1998). Enterprises, external economies, and economic development. Journal of Planning Literature, 2, 283-302.

Friedmann, J. (2005). Globalization and the emerging culture of planning. Progress in Planning, 64.

Gaubatz, P. (1999). China's urban transformation: Patterns and processes of morphological change in Beijing, Shanghai and Guangzhou. Urban Studies, 36, 1495-1521.

George, K. D. (1972). The changing structure of competitive industry. The Economic Journal, 82, 353-368.

Giuliano, G., Agarwal, A., \& Redfearn, C. (2008). Metropolitan spatial trends in employment and housing. In Special report 298: Driving and the built environment: The effects of compact development on motorized travel, energy use, and $\mathrm{CO}_{2}$ emissions.

Gordon, P., \& Richardson, H. W. (1996). Beyond polycentricity: The dispersed metropolis, Los Angeles, 1970-1990. Journal of the American Planning Association, 62, 289-295.

Gospodini, A. (2006). Portraying, classifying and understanding the emerging landscapes in the post-industrial city. Cities, 23, 311-330.

Gu, C., Chan, R. C. K., Liu, J., \& Kesteloot, C. (2006). Beijing's social-spatial restructuring: Immigration and social transformation in the epoch of national economic reformation. Progress in Planning, 66, 249-310.

Hall, P. (1997). The university and the city. GeoJournal, 41, 301-309.

Hallencreutz, D., \& Lundequist, P. (2003). Spatial clustering and the potential for policy practice: Experiences from cluster-building processes in Sweden. European Planning Studies, 11, 533-547.

Henry, N., \& Pinch, S. (2001). Neo-Marshallian nodes, institutional thickness, and Britain's 'Motor Sport Valley': Thick or thin? Environment and Planning A, 33, 1169-1183.

Hollands, R., \& Chatterton, P. (2003). Producing nightlife in the new urban entertainment economy: Corporatization, branding and market segmentation. International Journal of Urban E' Regional Research, 27, 361-385.

Hospers, G. J. (2005). Best practices and the dilemma of regional cluster policy in Europe. Tijdschrift Voor Economische En Sociale Geografie, 96, 452-457.

Hutton, T. A. (2004). The new economy of the inner city. Cities, 21, 89-108.

Hutton, T. A. (2006). Spatiality, built form, and creative industry development in the inner city. Environment and Planning A, 38, 1819-1841.

Jacobs, J. (1984). Cities and the wealth of nations: Principles of economic life. New York: Random House.

James, A. (2005). Demystifying the role of culture in innovative regional economies. Regional Studies, 39, 1197-1216.

Keeble, D., \& Nachum, L. (2002). Why do business service firms cluster? Small consultancies, clustering and decentralization in London and southern England. Transactions of the Institute of British Geographers, 27, 67-90.

Ketels, C. H. M. (2003). The development of the cluster concept: Present experiences and further developments. Harvard Business School.

Kim, J. Y. (2010). Does spatial clustering of foreign direct investment foster global production networks? The case of Qingdao, China. European Planning Studies, 19, 63-76.

Krugman, P. (1991a). Geography and trade. Cambridge: MIT Press.

Krugman, P. (1991b). Increasing returns and economic geography. Journal of Political Economy, 99, 483-499.

Lai, Y., Peng, Y., Li, B., \& Lin, Y. (2014). Industrial land development in urban villages in China: A property rights perspective. Habitat International, 41 185-194. 
Lees, L. (2003). Super-gentrification: The case of Brooklyn Heights, New York City. Urban Studies, 40, 2487-2509.

Liu, J. (2004). Suburban development based on regional integrity-what can Beijing learn from Paris for the rapid urbanization. Nanjing: Dongnan University Press.

Lorenzen, M. (2005). Why do clusters change? European Urban and Regional Studies, $12,203-208$

Marshall, A. (1919). Industry and trade. London: Macmillan.

Martin, R., \& Sunley, P. (2003). Deconstructing clusters: Chaotic concept or policy panacea? Journal of Economic Geography, 3, 5-35.

Maskell, P., \& Lorenzen, M. (2004). The cluster as market organisation. Urban Studies, 41, 991-1009.

McCann, P. (1995). Rethinking the economics of location and agglomeration. Urban Studies, 32, 563-577.

McDonald, F., Huang, Q. H., Tsagdis, D., \& Tuselmann, H. J. (2007). Is there evidence to support porter-type cluster policies? Regional Studies, 41, 39-49.

Mommaas, H. (2004). Cultural clusters and the post-industrial city: Towards the remapping of urban cultural policy. Urban Studies, 41, 507-532.

Moomaw, R. L. (1988). Agglomeration economies - Localization or urbanization. Urban Studies, 25, 150-161.

O'Sullivan, A. (2000). Urban economics (4th ed.). Boston: McGraw-Hill.

Parr, J. B. (1999). Growth-pole strategies in regional economic planning: A retrospective view: Part 1. Origins and advocacy. Urban Studies, 36, 1195-1215.

Parthasarathy, B. (2004). India's Silicon Valley or Silicon Valley's India? Socially embedding the computer software industry in Bangalore. International Journal of Urban and Regional Research, 28, 664-685.

Perroux, F. (1955). Note sur la notion de pôle de croissance. Economie Appliquée 307-320.

Phelps, N. A. (2004). Clusters, dispersion and the spaces in between: For an economic geography of the banal. Urban Studies, 41, 971-989.

Phelps, N. A., \& Ozawa, T. (2003). Contrasts in agglomeration: Proto-industrial, industrial and post-industrial forms compared. Progress in Human Geography, $27,583-604$.

Porter, M. E. (1990). The competitiveness advantage of nations. London: Basingstoke Macmillan.

Potter, A., \& Watts, H. D. (2011). Evolutionary agglomeration theory: Increasing returns, diminishing returns, and the industry life cycle. Journal of Economic Geography, 11, 417-455.

Richardson, G. B. (2003). The organization of industry re-visited. In DRUID summer conference on creating, sharing and transferring knowledge. The role of geography, institutions and organisations. Copenhagen.

Rosenfeld, S. A. (1995). Industrial strength strategies: Regional business clusters and public policy. Washington, DC: The Aspen Institute.
Rosenfeld, S. A. (1997). Bringing business clusters into the mainstream of economic development. European Planning Studies, 5, 3.

Rosenfeld, S. A. (2003). Expanding opportunities: Cluster strategies that reach more people and more places. European Planning Studies, 11, 359-377.

Rosenthal, S. S. \& Strange, W. C. (2004). Evidence on the nature and sources of agglomeration economies. In J. V. Henderson \& J. F. Thisse (Eds.). Handbook of regional and urban economics: Cities and geography (Vol. IV, pp. 2120-2167). Amsterdam, etc.: Elsevier.

Saxenian, A. L. (1994). Regional advantage: Culture and competition in Silicon Valley and Route 128. MA: Harvard University Press.

Schaller Consulting (2006). Necessity or choice? Why people drive in Manhattan. In Prepared for transportation alternatives (pp. 71). New York: Schaller Consulting.

Scott, A. J. (1985). Location processes, urbanization, and territorial development: An exploratory essay. Environment and Planning A, 17, 479-501.

Scott, A. J. (2004). Cultural-products industries and urban economic development: Prospects for growth and market contestation in global context. Urban Affairs Review, 39, 461-490.

Scott, A. J., \& Storper, M. (1987). High technology industry and regional development: A theoretical critique and reconstruction. International Social Science Journal, 112, 215-232.

Sforzi, F. (2002). The industrial district and the 'new' Italian economic geography. European Planning Studies, 10, 439-447.

Tan, J. (2006). Growth of industry clusters and innovation: Lessons from Beijing Zhongguancun Science Park. Journal of Business Venturing, 21, 827-850.

The World Bank (2008). World development report 2009: Reshaping economic geography (pp. 383). Washington, DC.

Walker, R. (2001). Industry builds the city: The suburbanization of manufacturing in the San Francisco Bay Area, 1850-1940. Journal of Historical Geography, 27, 36-57.

Wang, J., \& Wang, J. (1998). An analysis of new-tech agglomeration in Beijing: A new industrial district in the making. Environment and Planning A, 30, 681-701. Yang, Z., Cai, J., Ottens, H. F. L., \& Sliuzas, R. (2013). Beijing. Cities, 31, 491-506.

Yang, Z., Liang, J., \& Cai, J. (2014). Urban economic cluster template and its dynamics of Beijing, China. Chinese Geographical Science. http://dx.doi.org/10.1007/ s11769-014-0686-1.

Yang, Z., Sliuzas, R., Cai, J., \& Ottens, H. F. L. (2012). Exploring spatial evolution of economic clusters: A case study of Beijing. International Journal of Applied Earth Observation and Geoinformation, 19, 252-265.

Zhang, L., \& Zhao, S. X. (2009). City branding and the Olympic effect: A case study of Beijing. Cities, 26, 245-254.

Zhou, Y. (2005). The making of an innovative region from a centrally planned economy: Institutional evolution in Zhongguancun Science Park in Beijing. Environment and Planning A, 37, 1113-1134. 